\title{
Transaksi Lindung Nilai (Hedging) Dalam Praktik Perbankan Dan Implikasinya Terhadap Pembaruan Hukum Kontrak Nasional
}

\author{
Lastuti Abubakar, Tri Handayani \\ Dosen Fakultas Hukum Universitas Padjajaran Bandung \\ lastuti.abubakar@unpad.ac.id
}

\begin{abstract}
The monetary and economic crisis caused by a sharp exchange rate depreciation, thereby resulting in the businessmen and the Government is having difficulty in repaying foreign debt. Therefore required the efforts of deepening market through mechanisms of hedging (hedging) risk mitigation efforts as fluctuations in exchange rates. The Monetary Authority has published a set of rules about hedging (hedging) to give signs for banking transactions to facilitate hedging. This research aims to look at the benefits of hedging transactions, examine the position of the hedging transactions in the legal system of Indonesia agreement as well as a look at the implications of these hedging transactions against the renewal of the national contract law. The study method used is the juridical normative research specs are descriptive analytic. The data analyzed qualitative legally. Transactions hedging (hedging) is a technique to anticipate any loss incurred due to fluctuations in exchange rates. Hedging transactions is growing agreement in practice and can be classified as banking Covenants are not subject to the provisions of the named Book III $B W$. The development of objke and hedging transactions the enactment implicates Islamic hedging against the need to update national contract law.
\end{abstract}

Key words : hedging, banking transactions, contract law update

\begin{abstract}
Abstrak
Krisis ekonomi dan moneter disebabkan oleh depresiasi nilai tukar yang tajam, sehingga mengakibatkan pelaku usaha dan pemerintah mengalami kesulitan dalam membayar utang luar negeri. Oleh karena itu diperlukan upaya pendalaman pasar melalui mekanisme hedging (lindung nilai) sebagai upaya mitigasi risiko fluktuasi nilai tukar. Otoritas moneter telah menerbitkan serangkaian aturan tentang lindung nilai (hedging) guna memberikan rambu bagi perbankan untuk memfasilitasi transaksi lindung nilai. Penelitian ini bertujuan untuk melihat manfaat transaksi lindung nilai, mengkaji kedudukan transaksi lindung nilai dalam sistem hukum perjanjian Indonesia serta melihat implikasi dari transaksi lindung nilai ini terhadap pembaruan hukum kontrak nasional. Metode penelitan yang digunakan adalah yuridis normatif dengan spesifikasi penelitian bersifat deskriptif analitis. Data dianalisa secara yuridis kualitatif. Transaksi lindung nilai (hedging) merupakan teknik untuk mengantisipasi kerugian yang timbul akibat fluktuasi nilai tukar. Transaksi lindung nilai merupakan perjanjian yang berkembang dalam praktik perbankan dan dapat digolongkan sebagai perjanjian tidak bernama yang tunduk pada ketentuan Buku III KUHPerdata. Perkembangan objke transaksi lindung nilai dan diberlakukannya hedgin syariah berimplikasi terhadap perlunya pembaruan hukum kontrak nasional.
\end{abstract}

Kata Kunci : lindung nilai, transaksi perbankan, pembaruan hukum kontrak 


\section{Pendahuluan}

Berdasarkan hasil penelitian sebelumnya, krisis ekonomi dan moneter tahun 1997 disebabkan oleh depresiasi nilai tukar yang tajam sehingga mengakibatkan lonjakan beban angsuran dan pembayaran pokok utang luar negeri perusahaan (Indawan, et. al., 2012 : 4). Contoh depresiasi nilai tukar dapat dilihat dari fluktuasi nilai tukar rupiah terhadap US dolar pada minggu ketiga bulan juni tahun 2014.

\section{Grafik 1.}

\section{Grafik Nilai Tukar/USD April-Juni 2014}

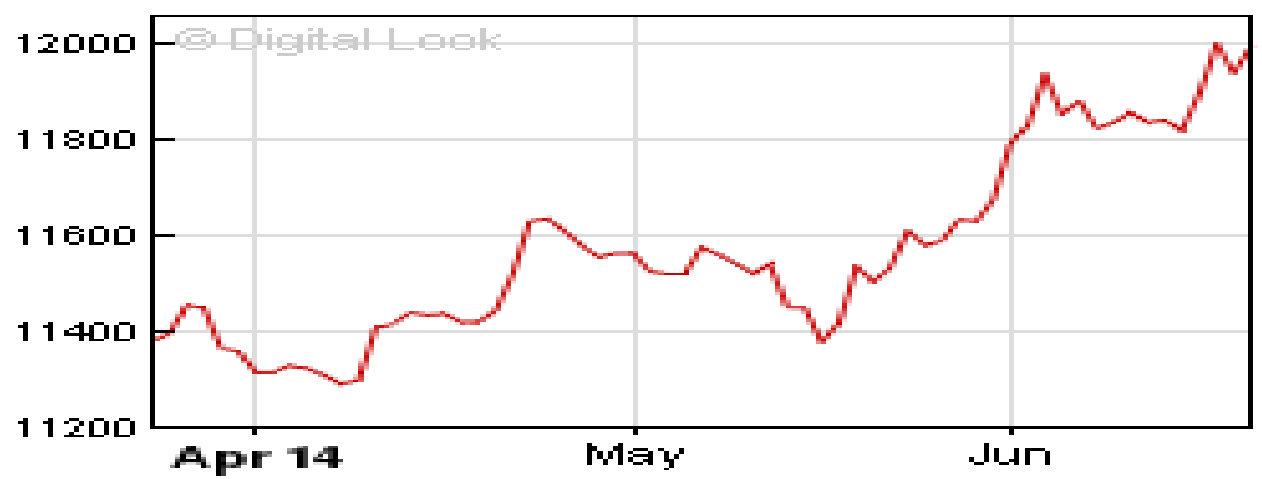

Sumber : Budi Sulistyo, Hedging Nilai Tukar Untuk mengurangi Risiko Pelebaran Defisit Anggaran, Sekretariat Jenderal- Kemenkeu.

Dibandingkan grafik nilai tukar pada tahun 2014, pada September 2016 grafik nilai tukar menunjukkan rupiah menguat.

Grafik 2.

\section{Kurs Trsansaksi USD Sept 2016}

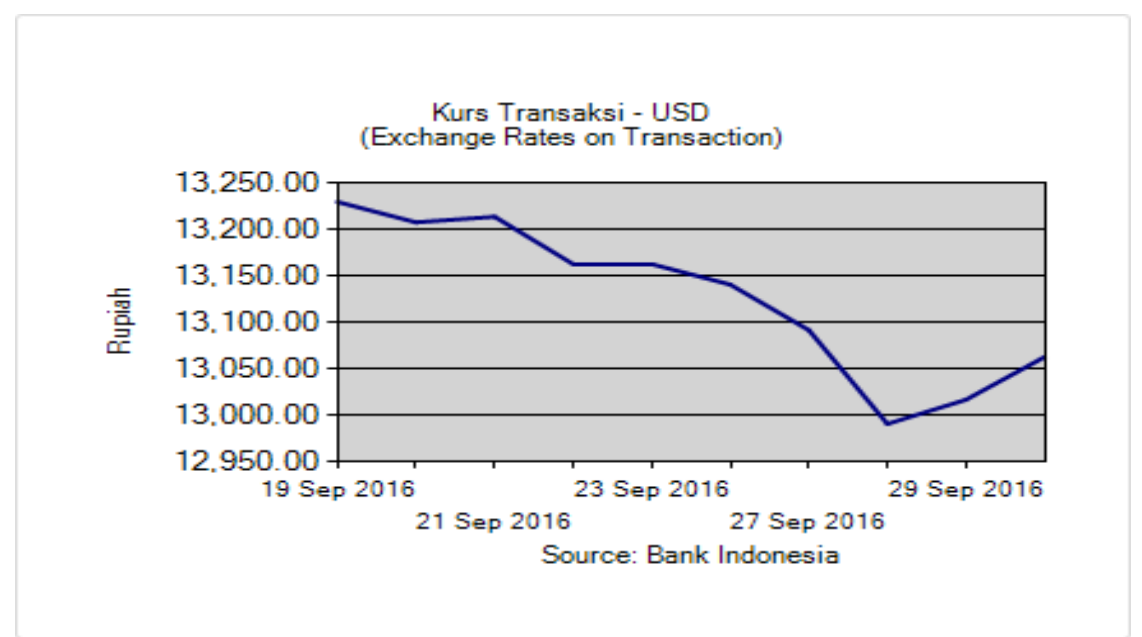

Sumber : Bank Indonesia, 2016. 
Dua grafik di atas menunjukkan bahwa nilai tukar rupiah terhadap mata uang asing, khususnya USD bersifat fluktuatif. Naik turun nilai rupiah terhadap valuta asing, membuat pelaku usaha kesulitan memenuhi kewajiban dalam membayar utang luar negeri dan berpotensi menimbulkan wanprestasi (ingkar janji) mengingat sebagian besar pendapatan diperoleh dalam mata uang rupiah. Selain berkaitan dengan utang luar negeri, fluktuasi mata uang juga dirasakan oleh para pelaku usaha, khususnya yang bergerak dalam usaha ekspor impor yang menggunakan mata uang berdenominasi dolar atau valuta asing lainnya. Melemahnya nilai tukar rupiah mempunyai dampak positif dan negatif. Dampak positif dirasakan oleh para eksportir yang menerima pembayaran dalam mata uang dolar Amerika, sedangkan dampak negatif dirasakan oleh pemerintah yang memiliki utang luar negeri berdenominasi dolar AS, yang semakin meningkat. Hal ini pernah terjadi dengan meningkatnya utang pemerintah Rp. 1.981 Triliun pada tahun 2012 menjadi Rp.2.275 triliun Pada Tahun 2013. Berdasarkan hasil pemeriksaan BPK atas laporan Keuangan Pemerintah Pusat Tahun 2013, kenaikan utang sebesar
Rp.163,24 triliun tersebut disebabkan selisih kurs. Hal ini berarti terjadi kenaikan utang namun tidak ada manfaatnya (Sulistyo, n.d.) Untuk mengantisipasi potensi risiko ketaksesuaian nilai tukar ( currency mismatch) sebagai akibat tajamnya depresiasi nilai tukar, perusahaan dituntut untuk melakukan lindung nilai (hedging) terhadap utang luar negeri agar dapat terhindar dari kebangkrutan (Sulistyo, n.d.) Berdasarkan permasalahan tersebut, dapat diidentifikasi beberapa hal sebagai berikut : 1) apa manfaat transaksi lindung nilai (hedging) dalam aktivitas bisnis? 2) bagaimana eksistensi transaksi lindung nilai dalam sistem hukum kontrak Indonesia?, 3) bagaimana implikasi transaksi lindung nilai terhadap pembaruan hukum kontrak nasional?.

\section{Metode Penelitian}

Metode pendekatan yang digunakan untuk menganalisa permasalahan adalah metode pendekatan yuridis normatif, dimana data yang digunakan merupakan data sekunder berupa bahan hukum primer yaitu peraturan perundang-undangan, bahan hukum sekunder dan tersier. Data yang diperoleh dianalisa secara yuridis kualitatif. Selanjutnyta, 
spesifikasi penelitian bersifat deskriptif analitis, dimana hasil analisa disajikan dalam bentuk paparan.

\section{Hasil Dan Pembahasan}

Lindung nilai ( hedging ) adalah cara atau teknik untuk mengurangi risiko yang timbul maupun akan timbul akibat fluktuasi harga di pasar keuangan (Vide No : 16/21/PBI/2014 Tentang Penerapan Prinsip Kehatihatian Dalam Pengelolaan Utang Luar Negeri Korporasi Non Bank). Dalam praktik perbankan tujuan hedging adalah untuk mengurangi risiko yang diperkirakan timbul dari transaksi atau investasi (Chorafas, 2008 :75), atau bertujuan untuk melakukan perlindungan atau proteksi terhadap aset dengan tujuan melakukan mitigasi risiko dari eksposur keuangan lain (Chisholm, 2010 : 3). Sebagai contoh, pada tahun 2015 PT. Perusahaan Listrik Negara (Persero) sebagai salah satu BUMN, menggunakan fasilitas hedging untuk memenuhi kebutuhan listrik nasional, akibat kewajiban utang luar negeri dan operasional dalam valuta uang asing, sementara pendapatan yang diterima dalam mata uang rupiah sehingga berdampak mismatch arus kas. Di lain pihak pergerakan nilai tukar rupiah diperkirakan masih akan terus berfluktuasi sebagai akibat membaiknya kondisi ekonomi Anerika Serikat dan adanya rencana The Fed ( Bank Central Amerika) melakukan normalisasi kebijakan moneter, dengan menaikkan suku bunga acuan ( Fed Fund Rate) di tahun 2015. Fasilitas hedging PLN diberikan oleh 3 Bank BUMN yaitu PT Bank Mandiri, Tbk, PT Bank BRI dan PT Bank BNI,Tbk. Bank Mandiri, Tbk mengambil porsi sebesar USD 500 juta dari total USD 950 juta. Kerjasama ini merupakan tindak lanjut dari Peraturan BUMN No PER-09/MBU/2013 tentang Kebijakan Umum Transaksi Lindung Nilai BUMN, PBI No : 16/21/PBI/2014 dan SEBI 16/24/DKEM Tentang Penerapan Prinsip Kehati-hatian Dalam Pengelolaan Utang Luar Negeri Korporasi Non Bank, dimana korporasi Non Bank harus memenuhi 3 pokok pengaturan yaitu rasio Lindung nilai, Rasio Likuiditas dan peringkat Utang. Dari sisi hukum, mekanisme hedging dilakukan dengan beberapa jenis transaksi derivatif yaitu : forwards, options dan swaps. Transaksi hedging di Indonesia belum digunakan secara optimal sebagai sarana pengelolaan risiko fluktuasi nilai rupiah.Berdasarkan hasil penelitian terdahulu diperoleh hasil bahwa 128 perusahaan keuangan non bank yang 
telah go public yang mempunyai kewajiban dalam mata uang asing, hanya 28 perusahaan atau sekitar $18 \%$ yang melakukan transaksi hedging, sementara itu perusahaan yang tidak melakukan ekspor tetapi melakukan kegiatan impor semakin bertambah hanya sebesar 11 perusahaan atau $9 \%$ yang melakukan transaksi hedging. Ke dua hal tersebut menunjukkan bahwa perusahaan berpotensi mengalami risiko currency mismatch. Berikut data yang memperlihatkan penggunaan hedging oleh perusahaan di Indonesia.

Tabel 2. Perkembangan Perusahaan yang Melakukan Transaksi Derivatif

\begin{tabular}{|c|c|c|c|c|c|c|c|c|c|}
\hline & rusahaan & 2005 & 2006 & 2007 & 2008 & 2009 & 2010 & 2011 & Rata2 \\
\hline \multirow[t]{3}{*}{ Ekspor } & derivatif & 19 & 25 & 28 & 33 & 20 & 23 & 15 & 23 \\
\hline & No derivatif & 55 & 50 & 48 & 42 & 57 & 54 & 60 & 52 \\
\hline & jumlah & 74 & 75 & 76 & 75 & 77 & 77 & 75 & 76 \\
\hline
\end{tabular}

\begin{tabular}{clllllllll}
\hline $\begin{array}{l}\text { No } \\
\text { ekspor }\end{array}$ & Derivatif & 4 & 6 & 8 & 11 & 4 & 2 & 5 & 6 \\
\hline \multirow{2}{*}{ No Derivatif } & 50 & 47 & 44 & 42 & 47 & 49 & 48 & 47 \\
\hline & Jumlah & 54 & 53 & 52 & 53 & 51 & 51 & 53 & 52 \\
\hline Persentase & $\mathbf{2 0 0 5}$ & $\mathbf{2 0 0 6}$ & $\mathbf{2 0 0 7}$ & $\mathbf{2 0 0 8}$ & $\mathbf{2 0 0 9}$ & $\mathbf{2 0 1 0}$ & $\mathbf{2 0 1 1}$ & Rata2 \\
\hline Ekspor & Derivatif & 15 & 20 & 22 & 26 & 16 & 18 & 12 & 18 \\
\hline & No Derivatif & 43 & 39 & 38 & 33 & 45 & 42 & 47 & 41 \\
\hline & Jumlah & 58 & 59 & 59 & 59 & 61 & 60 & 59 & 59 \\
\hline
\end{tabular}

\begin{tabular}{llllllllll}
\hline $\begin{array}{l}\text { No } \\
\text { ekspor }\end{array}$ & Derivatif & 3 & 5 & 6 & 9 & 3 & 3 & 4 & 4 \\
\hline & No Derivatif & 39 & 37 & 34 & 33 & 37 & 38 & 38 & 36 \\
\hline & Jumlah & 42 & 41 & 41 & 42 & 40 & 40 & 41 & 41 \\
\hline
\end{tabular}

Sumber : Fiskara Indawan dkk, 2012, Pengaruh Pelindungan Nilai Tukar Terhadap

Utang Luar Negeri Dan Kinerja Perusahaan, Working Paper, Bank Indonesia.

Regulasi Lindung Nilai (hedging) di

\section{Indonesia}

Praktik lindung nilai (hedging) oleh pelaku usaha yang difasilitasi oleh perbankan Indonesia tidak dapat dilepaskan dari KUHPerdata, khususnya Buku II Tentang Benda dan Buku III Tentang Perikatan sebagai lex generalis. Sebagai perjanjian yang 
berkembang dalam praktik perbankan, keberadaan transaksi lindung nilai ini dimungkinkan berdasarkan sistem terbuka dan asas kebebasan berkontrak yang dianut oleh KUHPerdata, khususnya berkaitan dengan keabsahan perjanjian yang diatur dalam Pasal 1320. Selanjutnya, ketentuan khusus yang mengatur eksistensi hedging diatur dalam beberapa peraturan perundang-undangan antara lain UU Perbankan dan UU Pasar Modal sebagai lex specialis. Dengan demikian, terhadap aktivitas hedging berlaku asas lex specialis derogat lex specialis. Dalam praktik, ketentuan hedging dalam aktivitas perbankan ditindaklanjuti dengan penerbitan Peraturan Bank Indonesia (PBI). Bank Indonesia telah menerbitkan beberapa PBI dan perubahannya yang mengatur tentang aktivitas lindung nilai. Bank Indonesia telah menyempurnakan aturan tentang lindung nilai dalam 4 PBI, dimana 2 aturan merupakan peleburan dari $6 \mathrm{PBI}$, sedangkan 2 lainnya merupakan perubahan dan penyempurnaan PBI sebelumnya. Berikut pemetaan regulasi yang menjadi landasan hukum bagi aktivitas lindung nilai dalam aktivitas perbankan.

Tabel 2. Pemetaan regulasi yang berkaitan dengan aktivitas lindung nilai dalam praktik perbankan

\begin{tabular}{|c|c|c|c|}
\hline No & Peraturan & Substansi & Keterangan \\
\hline 1 & KUHPerdata & $\begin{array}{l}\text { Buku II Tentang Benda } \\
\text { dan Buku III Tentang } \\
\text { Perikatan }\end{array}$ & $\begin{array}{l}\text { Pedoman } \\
\text { Penyusunan SOP } \\
\text { Kegiatan Lindung } \\
\text { Nilai (Hedging) }\end{array}$ \\
\hline 2 & $\begin{array}{lrll}\text { PBI } & \text { No } & : & 16 / 17 \\
/ \mathrm{PBI} / 2014 & & \end{array}$ & $\begin{array}{l}\text { Transaksi Valas Terhadap } \\
\text { Rupiah Antara Bank } \\
\text { dengan Pihak Asing }\end{array}$ & \\
\hline 3 & $\begin{array}{l}\text { PBI No } \\
\text { PBI/2014 }\end{array}$ & $\begin{array}{l}\text { Transaksi Lindung Nilai } \\
\text { kepada Bank }\end{array}$ & $\begin{array}{l}\text { Perubahan dari } \\
\text { PBI No : } \\
\text { 15/8/PBI/2013 }\end{array}$ \\
\hline 4 & $\begin{array}{l}\text { PBI No } \\
/ \mathrm{PBI} / 2014\end{array}$ & $\begin{array}{lr}\text { Transaksi Swap } & \text { Lindung } \\
\text { Nilai kepada } & \text { Bank } \\
\text { Indonesia } & \end{array}$ & $\begin{array}{l}\text { Perubahan dari } \\
\text { PBI No : } \\
\text { 15/17/PBI/2013 }\end{array}$ \\
\hline 5 & PBI & Transaksi Valas Terhadap & Perubahan ketiga \\
\hline
\end{tabular}




\begin{tabular}{|c|c|c|}
\hline & 17/15/PBI/2015 & $\begin{array}{llll}\text { Rupiah Antara Bank atas PBI No : } & \text { Pomestik. } & \text { 16/16/PBI/2014 }\end{array}$ \\
\hline 6 & PBI No : 18/2/PBI/2016 & $\begin{array}{l}\text { Transaksi Lindung Nilai } \\
\text { Berdasarkan } \\
\text { Syariah }\end{array}$ \\
\hline 7 & $\begin{array}{l}\text { Peraturan } \\
\text { Keuangan } \quad \text { No : } \\
\text { 12.PMK.08/2013 }\end{array}$ & $\begin{array}{l}\text { Transaksi Lindung Nilai } \\
\text { dalam Pengelolaan Utang } \\
\text { Pemerintah. }\end{array}$ \\
\hline 9 & SEBI No: 17/49/DPM & 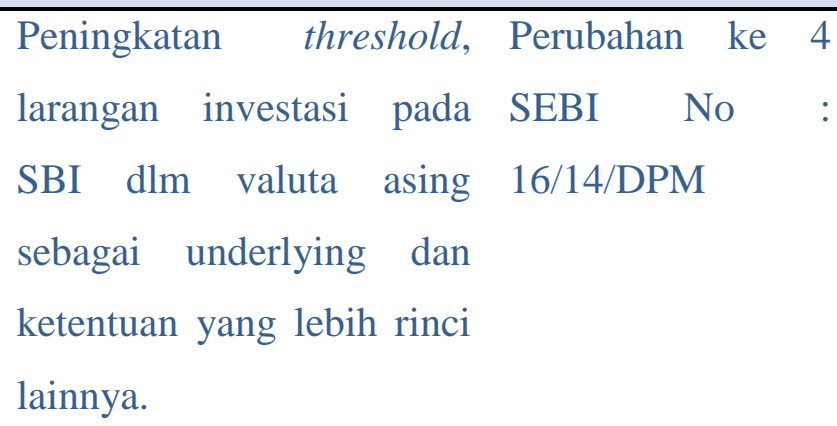 \\
\hline 10 & S- 687/MBU/10/2014 & $\begin{array}{ll}\text { Pedoman Penyusunan SOP } & \text { Khusus } \\
\text { Kegiatan Lindung Nilai } & \text { BUMN } \\
\text { (Hedging) } & \\
\end{array}$ \\
\hline
\end{tabular}

Sumber : diolah oleh Penulis

Sejalan dengan perkembangan dan dinamika baik di domestik maupun di tataran global, review terhadap ketentuan transaksi valuta asing terus dilanjutkan untuk mendorong pendalaman pasar keuangan sehingga

likuid, efisien dan aman guna mendukung stabilitas nilai tukar dan pertumbuhan ekonomi yang berkelanjutan. Seluruh penyesuaian pengaturan tersebut diharapkan dapat mendukung upaya-upaya meningkatkan kapasitas perdagangan dan investasi di dalam negeri, melalui peningkatan fleksibilitas transaksi oleh pelaku ekonomi. Selain itu penyesuaian juga dilakukan secara prudent dan tetap memperhatikan dampak terhadap stabilitas sistem keuangan. Bank diwajibkan untuk memenuhi pengaturan-pengaturan terkait mitigasi risiko, sebagaimana yang telah diatur pula oleh otoritas perbankan. Selain PBI, unutk BUMN berlaku Peraturan Menteri Keuangan No : 12.PMK.08/2013 Tentang Transaksi Lindung nilai dalam Pengelolaan Utang Pemerintah. Berdasarkan PMK 
No.12.PMK.08/2013 diatur bahwa pemerintah dapat melakukan hedging untuk memitigasi risiko atau melindungi suatu aset atau kewajiban yang mendasarinya (underlying asset) terhadap risiko fluktuasi tingkat suku bunga dan nilai mata uang di masa yang akan datang. Selain utang luar negeri, PMK juga memungkinkan hedging untuk dan obligasi mata uang asing yang diterbitkan dan pinjaman internasional yang diambil pemerintah. Landasan penerbitan PMK ini didasarkan pada Pasal 26 Ayat 4 UU No : 19 Tahun 2012 Tentang APBN 2013, yang mendukung bahwa transaksi hedging yang dilakukan pemerintah tidak akan dianggap sebagai kerugian negara. Lindung nilai oleh Pemerintah ini meliputi transaksi pengelolaan utang pemerintah dalam bentuk pinjaman, dan atau surat berharga negara.

\section{Manfaat Hedging dalam Aktivitas}

\section{Bisnis}

Bank Indonesia menegaskan bahwa transaksi lindung nilai (hedging) penting untuk dilaksanakan, mengingat manfaat dari pelaksanaan lindung nilai bagi kepentingan makroekonomi yaitu mampu menjaga stabilitas nilai tukar, meminimalkan sovereign risk akibat risiko gagal bayar pinjaman luar negeri sektor swasta, menjaga integritas sektor keuangan Indonesia, menciptakan pasar valas domestik yang lebih sehat dan berkembang serta meningkatkan kepercayaan investor terhadap pasar keuangan Indonesia. Sedangkan bagi BUMN dan pelaku usaha, hedging bermanfaat untuk mengurangi risiko keuangan dalam bentuk adanya kepastian kalkulasi cashflow dan penetapan harga pokok produk (HPP), meningkatkan manajemen risiko internal BUMN terkait eksposur nilai tukar serta meningkatkan kepercayaan investor . Dalam konteks ini, peraturan Menteri Keuangan dan Peraturan Menteri BUMN tidak membuka kemungkinan hedging digunakan sebagai instrument investasi yang sifatnya spekulatif. Oleh karena itu, Pasal 4 Peraturan Menteri BUMN menegaskan bahwa BUMN harus memperhatikan prinsip-prinsip sebagai berikut :

a. tata kelola perusahaan yang baik (good corporate governance).

b. Penerapan manajemen risiko

c. Standar akuntansi dan perpajakan.

Berdasarkan PBI dan Peraturan tentang Hedging bagi BUMN, dapat disimpulkan bahwa transaksi lindung nilai ( hedging) mempunyai manfaat yang sangat penting, yakni : 
a. Sebagai fungsi lindung nilai (hedging); dengan melakukan transaksi lindung nilai, utang pemerintah atau kewajiban BUMN dalam bentuk valuta asing akan dibayar sesuai kurs valuta asing terhadap rupiah sesuai yang telah disepakati. Dengan demikian, pemerintah /BUMN akan terhindar dari meningkatnya utang akibat kenaikan selisih kurs rupiah dengan valuta asing sehingga likuditas dan kemampuan ekonomi pemerintah/BUMN dapat terjaga.

b. Sebagai sarana untuk mengendalikan risiko; khususnya risiko pasar yang mungkin dihadapi oleh para pelaku usaha berupa risiko tingkat suku bunga atau ekuitas yang dimiliki oleh perusahaan.

c. Meningkatkan kepercayaan lembaga keuangan dan perbankan terhadap pelaku usaha, mengingat dengan melakukan transaksi lindung nilai aktivitas perusahaan lebih mapan dan stabil, sehingga memberikan keumungkinan lebih besar bagi perusahaan untuk mendapatkan akses pembiayaan.

Transaksi Lindung Nilai (hedging) Sebagai Perjanjian yang Berkembang dalam Praktik Perbankan

Sebagaimana telah diuraikan sebelumnya, aktivitas hedging berlandaskan pada kontrak (perjanjian tertulis) diantara para pihak yang diperkenankan berdasarkan sistem terbuka (vide Pasal 1319 KUHPerdata) dan asas kebebasan berkontrak (Vide Pasa 1338 ayat (1) KUHPerdata) yang dianut oleh Buku III KUHPerdata. Dengan demikian, dapat dikatakan bahwa transaksi lindung nilai , khususnya lindung nilai terhadap valuta asing (currency hedging ) yang difasilitasi oleh perbankan, merupakan perjanjian tidak bernama yang berkembang dalam praktik perbankan. Oleh karena itu, terhadap transaksi hedging berlaku ketentuan umum tentang perjanjian yang diatur dalam Buku III KUHPerdata Tentang Hukum Perikatan, khususnya tentang keabsahan kontrak hedging. Prinsipprinsip perjanjian yang diatur dalam Buku III berlaku disamping prinsip khusus yang harus dipatuhi dalam transaksi hedging sesuai ketentuan yang berlaku, terutama prinsip kehatihatian bank (prudential banking principle) sebagai prinsip utama yang diatur dalam UU No : 10 Tahun 1998 
Tentang Perubahan UU No : 7 Tahun 1992 Tentang Perbankan (Vide Pasal 2, 8, dan 29 UU Perbankan). Selain itu, berdasarkan PBI, setiap Bank yang melaksanakan transaksi hedging wajib mempunyai pedoman. Khusus BUMN, pedoman penyusunan standar kegiatan lindung nilai (hedging) memuat subtansi penting dalam pelaksanaan hedging dalam BUMN, seperti kewenangan perangkat yang menangani hedging serta tahapan dalam pelaksanaan hedging.

Berdasarkan pedoman, tahapan dalam transaksi hedging meliputi :

a. Tahapan persiapan transaksi; yang meliputi rencana tanksaksi , keputusan strategi pelaksanaan, persiapan kontrak, penetapan counterpart dan pembukaan forex line serta penetapan limit.

b. Tahap Pelaksanaan Transaksi; yang meliputi monitoring limit, price checking, eksekusi transaksi dan konfirmasi

transaksi/penandatanganan kontrak.

c. Tahap Monitoring s.d Penyelesaian Transaksi ; meliputi pencatatan akuntansi transaksi hedging; pelaksanaan marking to market dan setelmen transaksi.

d. Dokumentasi ; e. Pelaporan dan evaluasi; yang meliputi laporan pelaksanaa transaksi, rekapitulasi transaksi hedging; laporan mark to market; laporan hasil monitoring atas mark to market, evaluasi efektivitas transaksi hedging dan evaluasi berkala terhadap kecukupan SOP.

Berdasarkan regulasi sebagaimana telah diuraikan sebelumnya, transaksi lindung nilai (hedging) ini jenisnya bergantung pada transaksi derivatif yang digunakan, yaitu forward, option dan swap, termasuk cross currency swap. Oleh karena itu perlu difahami betul apa yang dimaksud dengan ke 3 derivatif tersebut, yaitu :

a. Transaksi forward : yaitu transaksi jual/beli valuta asing yang penyerahan dananya dilakukan lebih dari dua hari kerja setelah tanggal transaksi (deal date). Secara umum transaksi forwards dapat dilihat dari definisi yang diberikan oleh Paul Wilmott bahwa " a forwards contract is an agreement when one party promises to buy an asset from another party at some specified time in the future and some specified price (Willmott, 1998 : 16). Dalam praktik forwards ini mirip dengan Futures (kontrak 
berjangka), dimana perbedaannya futures diperdagangkan pada pasar yang terorganisasi (bursa), dengan menggunakan kontrak standar (Chance, n.d. : 264). Kontrak forwards berdasarkan kesepakatan para pihak dan tidak diperdagangkan di bursa yang terorganisasi. Dapat dikatakan bahwa forwards inilah asal muasal timbulnya futures. Don M Chance secara sederhana mendefinisikan forwards sebagai "contract for the sale and delivery of commodity on a later date at a price agreed upon today. Forwards secara aktif diperdagangkan di pasar yang memperdagangkan valuta asing (foreign exchange), yang biasa disebut Interbank Market. Para pihaknya dapat berupa Bank, perusahaan, dan pemerintah. Kontrak forward dapat digunakan baik sebagai lindung nilai maupun untuk berspekulasi atas suku bunga atau nilai mata uang. Sama halnya dengan transaksi derivatif lainnya, dalam forwards tidak dibutuhkan penyerahan secara nyata objek sebagaimana dalam jual beli konvensional.

b. Transaksi Swap adalah transaksi jual/beli valuta asing melalui pembelian/penjualan dengan penjualan/pembelian kembali secara berjangka yang dilakukan secara simultan dengan counterparty yang sama dan pada tingkat harga yang ditentukan dan disepakati pada deal date, atau tanggal dimana terjadi kesepakatan/kontrak transaksi hedging valuta asing dengan counterparty. Jenis derivatif swap ini berkembang khusus di dunia perbankan. Transaksi swap juga diartikan sebagai transaksi finansial antara 2 pihak yang sepakat untuk bertukar arus kas selama periode tertentu yang telah ditentukan (Sembel \& Fardiansyah, 2002 : 11). Pengertian ini sejalan dengan pendapat lain, seperti Paul Wilmott yang mendefinisikan swap sebagai “ an agreement between two parties to exchange,or swap, future cashflows (Willmot, 1998 : 419). Definisi lain diberikan Don $\mathrm{M}$ Chance, bahwa " swap is a contract in which two parties agree to exchange cash flow" (Chance, n.d. : 264).

c. Transaksi option adalah perjanjian untuk memberikan hak dan bukan kewajiban dari penjual (option writer) kepada pembeli ( option holder) untuk membeli atau menjual sejumlah nominal mata 
uang tertentu untuk masa yang akan datang pada harga yang telah ditetapkan sebelumnya (strike price) pada atau sebelum waktu tertentu ( expiry date). Don $\mathrm{M}$ Chance menefinisikan options sebagai " a contract between two parties - a buyer and a seller, or writer-in which purchase from the writer the right to buy or selling an asset at a fixed price (Chance, n.d. : 28). Selain diperdagangkan di pasar yang terorganisir, options memiliki jangka waktu (expiration date), artinya hak untuk membeli dan menjual aset pada harga tertentu diakui khusus dalam jangka waktu tertentu. Dalam praktik, terdapat dua tipe options, yaitu opsi Eropa (European Options) dan opsi Amerika (American Options). Perbedaan diantara keduanya adalah, dalam opsi Eropa, pemilik dapat menggunakan haknya hanya pada saat opsi jatuh tempo, sedangkan dalam opsi Amerika, pemilik dapat menggunakan haknya sebelum atau pada saat jatuh tempo. Keuntungan yang diperoleh pemilik opsi bergantung pada nilai (pay off) pada saat opsi jatuh tempo.dalam hal call option, dimana harga dasar lebih tinggi dari exercise price atau disebut in the money maka pemilik opsi sebaiknya melaksanakan haknya karena akan menguntungkan, sebaliknya apabila harga dasarnya lebih rendah atau out the money, maka sebaiknya hak tidak dilaksanakan (Willmot, 1998 : 21). Saat ini opsi yang paling banyak diperdagangkan adalah opsi yang underlying asset nya adalah saham (stock option).

Apabila dicermati ke tiga jenis transaksi derivatif diatas, maka yang menjadi objek transaksi adalah kesanggupan atau janji untuk membeli aset di masa yang akan datang dengan harga yang telah disepakati (forward) ; jual beli dengan mempertukarkan arus kas (swap); serta hak untuk membeli atau menjual aset tertentu di masa yang akan datang dengan harga yang telah ditentukan sebelumnya (option). Dengan kata lain objek yang ditransaksikan belum secara eksplisit masuk dalam pengertian barang dalam $\begin{array}{llll}\text { pengertian } & \text { Pasal } & 1332 & -1334\end{array}$ KUHPerdata, yang menyebutkan bahwa objek perjanjian adalah “ barang yang dapat diperdagangkan” atau " barang yang akan ada dikemudian hari”. Dengan demikian, dapat dikatakan bahwa praktik hedging 
mengembangkan pengertian barang

kontrak konvensional yang sebagai objek perjanjian. Selain mengembangkan objek, terbitnya PBI tentang Hedging syariah turut memperkaya hukum kontrak nasional dengan berlakunya kontrak berdasarkan prinsip syariah sebagai bagian dari sistem hukum kontrak nasional.

\section{Pembaruan Hukum Kontrak Nasional}

Buku III KUHPerdata memberi keleluasaan bagi para pihak untuk membuat perjanjian/kontrak dengan nama baru, serta bebas menentukan klausula yang akan disepakati. Kehadiran transaksi lindung nilai dalam praktik perbankan telah mengubah tatanan hukum kontrak nasional. Perkembangan pengertian barang dan berlakunya prinsip syariah dalam aktivitas hedging yang belum diakomodasikan dalam KUHPerdata, berimplikasi terhadap urgensi pembaruan hukum KUHPerdata pada umumnya, khususnya hukum benda dan hukum kontrak . Dapat dikatakan, saat ini terjadi dualisme hukum perdata, yakni berlakunya lebih dari sistem hukum, yaitu konvensional dan syariah, disamping hukum perdata Adat yang di beberapa tempat tertentu masih berlaku. Kaidah dalam hukum bertentangan dengan prinsip syariah tidak dapat digunakan dalam transaksi lindung nilai (hedging syariah). Berikut beberapa substansi yang membedakan hedging syariah dengan hedging konevensional berdasarkan PBI No : 18/2/PBI/2016 Tentang Transaksi Lindung Nilai Berdasarkan Prinsip Syariah (Hedging Syariah) :

a. Transaksi lindung nilai syariah harus didahului dengan forward agreement atau rangkaian forward agreement. Forward agreement adalah saling berjanji (muwa'adah) untuk melakukan transaksi spot dalam jumlah tertentu di masa yang akan datang dengan nilai tukar atau perhitungan nilai tukar yang disepakati pada saat saling berjanji. Apabila forward agreement tidak dipenuhi maka pihak yang tidak emmenuhi dapat dikenakan ganti rugin(ta'widh).

b. Nilai tukar dan perhitungan nilai tukar harus ditentukan pada saat forward agreement dan tidak boleh bertentangan dengan prinsip syariah.

c. Hal yang harus diperhatikan dalam melakukan transaksi lindung nilai berdasarkan prinsip syariah dapat dilihat dalam tabel berikut : 
Tabel 1.

Hal yang harus diperhatikan dalam melakukan transaksi lindung nilai berdasarkan prinsip syariah

\begin{tabular}{|c|c|c|}
\hline No & Kriteria & Keterangan \\
\hline 1 & Tujuan & $\begin{array}{l}\text { Bukan untuk spekulatif, sehingga wajib memiliki underlying } \\
\text { transaksi }\end{array}$ \\
\hline 2 & Lara & Dokumen forward agreement tidak bolej diperjualbelikan \\
\hline 3 & $\begin{array}{l}\text { Nilai } \\
\text { nominal }\end{array}$ & $\begin{array}{l}\text { Nilai nominal transaksi paling banyak sebesar nilai nominal } \\
\text { underlying transaksi }\end{array}$ \\
\hline 4 & $\begin{array}{l}\text { Jangka } \\
\text { waktu }\end{array}$ & $\begin{array}{l}\text { Sama dengan jangka waktu underlying transaksi yang tercantum } \\
\text { dalam dokumen underlying }\end{array}$ \\
\hline 5 & $\begin{array}{l}\text { Penyelesaia } \\
\text { n Transaksi }\end{array}$ & Wajib dilakukan denga \\
\hline 6 & Pembatalan & $\begin{array}{l}\text { Pembatalan transaksi lindung nilai syariah yang telah diikuti } \\
\text { dengan pemindahan dana wajib dilakukan dengan pengembalian } \\
\text { dana secara penuh }\end{array}$ \\
\hline 7 & Jenis & $\begin{array}{l}\text { Transaksi lindung nilai sederhana (aqd al Tahawwuth al-Basith) } \\
\text { atau transaksi lindung nilai kompleks (Aqd al Tahawwuth al } \\
\text { Murakkab) }\end{array}$ \\
\hline 8 & $\begin{array}{l}\text { Underlying } \\
\text { transaksi }\end{array}$ & $\begin{array}{l}\text { a. Perdagangan barang dan jasa di dalam dan luar negeri } \\
\text { b. Investasi berupa direct invesment, portfolio inversment, } \\
\text { pembiayaan, modal dan investasi lain di dalam dan luar } \\
\text { negeri. }\end{array}$ \\
\hline
\end{tabular}

Sumber : PBI No : 18/2/PBI/2016.

Berdasarkan tabel diatas, maka hukum kontrak nasional sudah saatnya mengakomodasikan perkembangan kontrak berdasarkan prinsip syariah. Mengenai bagaimana bentuk pembaruan hukum kontrak dengan keberadaan kontrak syariah, dapat dipilih beberapa opsi, antara lain :

a. mengatur bersama-sama kontrak berdasarkan syariah dan kontrak konvensional dalam satu peraturan perundang-undangan; 
b. membentuk KUHPerdata Islam sebagai ketentuan umum (lex generalis).

c. Mengatur secara parsial pranata syariah tertentu sesuai dengan kebutuhan.

Dalam praktik, politik pembaruan hukum di Indonesia menganut sistem kodifikasi parsial, artinya pembentukan regulasi didasarkan pada urgensitas substansi yang akan diatur. Berkaitan dengan berlakunya aktivitas ekonomi berdasarkan prinsip syariah, Indonesia telah melakukan opsi membentuk regulasi secara bertahap dan memisahkan regulasi untuk aktivitas berdasarkan prinsip syriah dengan konvensional. Sebagai contoh, semula aktivitas perbankan syariah sudah dimanatkan dalam UU No : 10 Tahun 1998 Tentang Perubahan UU No: 7Tahun 1992 Tentang Perbankan. Pada tahun 2008, terbit UU No : 21 Tahun 2008 Tentang Perbankan Syariah. Model pembentukan hukum yang demikian tampaknya lebih tepat dalam pembaruan hukum kontrak nasional, dimana saat ini kontrak (akad) berdasarkan prinsip syariah masih diatur secara tersebar dengan tetap bersumber pada Fatwa Dewan Syariah Nasional (DSN), Kompilasi Hukum Ekonomi Islam dan peraturanperaturan lain seperti PBI dan POJK, namun di kemudian hari perlu dipikirkan pembentukan undangundang khusus yang mengatur hukum perdata Islam sebagai lex generalis.

Selain Buku III, berkaitan dengan implikasi transaksi lindung nilai terhadap pembaruan hukum kontrak, maka perlu dipikirkan redefinisi tentang benda atau barang sebagai objek perjanjian. Perkembangan objek perjanjian telah jauh berkembang, meninggalkan konsep benda sebagaimana diatur dalam Buku II KUHPerdata. Mengingat KUHPerdata berasal dari Burgerlijk Wetboek Belanda yang diberlakukan berdasarkan asas konkordansi, dan Indonesia menganut sistem hukum yang sama dengan dengan Belanda, yaitu civil law system, tentunya model pembaruan hukum perdata Belanda dapat dijadikan acuan. Niuewe Burgerlijk Wetboek (NBW) tidak lagi menggunakan istilah zakerrecht untuk hukum benda, melainkan goedererecht. Di dalam NBW Buku 1 Titel 1 pada 3.art 1 (3.1.1.0) didefinisikan bahwa “ goederen zijn alle vermogenrechten" yaitu "barang terdiri atas semua benda dan semua hak kekayaan" (Hasan, 1996 : 248). Istilah goederen dalam NBW sama dengan zaak dalam BW lama atau KUHPerdata Indonesia. Selanjutnya NBW mengatur bahwa 
"goederen zijn alle actieven vermogen bestandelen", yaitu barang adalah semua unsur aktif harta kekayaan. Dengan demikian, NBW telah meperluas pengertian benda, tidak hanya meliputi barang dan hak yang dapat dikuasai hak ilik, melainkan mencakup semua unsur aktif dari harta kekayaan. Penulis mencermati bahwa pembaruan hukum perdata di Belanda mempengaruhi juga bidang hukum lainnya yang selaras dengan hukum bendanya. Hal ini dapat dilihat dari diaturnya perjanjian khusus yang mengatur tentang naik turunnya niai uang, yang dalam BW lama dikategorikan sebagai perjanjian untung-untungan. Dengan demikian, naik turunya nilai uang atau harga saham atau derivatif lainnya dipastikan masuk ke dalam pengertian benda menurut NBW (Abubakar, 2015). Hal ini akan memberikan rasa ama bagi para pihak dalam bertransaksi, termasuk transaksi lindung nilai (hedging). Dengan demikian, NBW telah dapat mengantisipasi dan mengakomodasikan perkembangan benda sehingga tidak akan menjadi permasalahan kalau objek transaksi atau objek jaminan berupa nilai ekonomi dari suatu barang atau hak. Menurut pendapat penulis, pembaruan hukum kontrak nasional, termasuk pembaruan hukum benda nasional dapat mengikuti model pembaruan hukum di Belanda. Selain itu penulis mengusulkan, bahwa sekurangkurangnya pengertian benda meliputi segala sesuatu yang bernilai ekonomi dan bermanfaat bagi kehidupan manusia. Perluasan pengertian benda tentu harus selaras dengan tujuan pembangunan nasional, oleh karena itu eksploitasi benda atau unsur benda semata mata untuk memenuhi kepentingan ekonomi namun menimbulkan kehancuran manusia maupun alam, tanpa batas tidaklah diperkenankan (Abubakar, 2015). Disinilah hukum berfungsi sebagai sarana pembaharuan dengan tetap memperhatikan tujuannya yaitu terjadinya perubahan dengan tetap memelihara ketertiban dan keteraturan (Kusumaatmadja, 2002 : 20).

\section{Kesimpulan}

Berdasarkan analisa dan pembahasan yang telah diuraikan sebelumnya, dapat disimpulkan sebagai berikut :

1. Lindung Nilai ( hedging)
berfungsi sebagai instrumen
pengendalian risiko berupa
kerugian akibat fluktuasi nilai
tukar, yang manfaatnya dapat
dapat dirasakan baik oleh


pemerintah maupun pelaku usaha termasuk BUMN. Bagi bank, transaksi lindung nilai juga dapat meningkatkan kepercayaan terhadap pelaku usaha, mengingat dengan melakukan transaksi lindung nilai aktivitas perusahaan lebih mapan dan stabil, sehingga memberikan kemungkinan lebih besar bagi perusahaan untuk mendapatkan akses pembiayaan.

2. Transaksi Lindung Nilai (hedging) merupakan salah satu perjanjian/kontrak yang berkembang dalam praktik bisnis, khususnya dalam aktivitas perbankan berdasarkan sistem terbuka dan asas kebebasan berkontrak yang diatur dalam Buku III KUHPerdata. Selain tunduk pada ketentuan dalam KUHPerdata, transaksi lindung nilai diatur dalam PBI sebagai otoritas moneter dan peraturan Menteri Keuangan dan Peraturan Kementerian BUMN, yang secara khusus mengatur transaksi lindung nilai bagi BUMN.

3. Praktik lindung nilai berimplikasi terhadap gagasan pembaruan hukum kontrak dan hukum benda, mengingat transaksi lindung nilai ini selain menggunakan kaidah2 yang diatur dalam KUHPerdata, juga berdasarkan prinsip syariah, yang mengakibatkan dualisme hukum kontrak, yang masih memerlukan landasan hukum yang komprehensif. Selain itu, transaksi lindung nilai memperluas lingkup objek perjanjian yang diatur dalam Buku II dan Buku III yang mengatur tentang benda sebagai objek transaksi dan pengertian barang sebagai objek transaksi.

\section{DAFTAR PUSTAKA}

Chance, Don. M.,1998, An Introduction To Derivatives, New York : The Dryden Press, Harcourt Brace Colleges Publisher.

Chisholm, Andrew M., 2010, Derivatives- A Step by Step Guide to Forwards, Futures, Swaps and Options, United Kingdom : A John Wiley \& Sons Limited Publication.

Chofaras, Dimitri N, 2008, Introduction To derivatives Financial Instrument- Options, Futures, Forwards, Swaps and Hedging, New York : Mc Graw Hill,

Indawan, Fiskara, dkk, 2012, Pengaruh Pelindungan Nilai Tukar Terhadap Utang Luar Negeri Dan Kinerja Perusahaan, Jakarta : Bank Indonesia. 
Hasan, Djuhaendah, 1996, Lembaga Jaminan Bagi Tanah Dan Benda Lain Yang Melekat pada Tanah Dalam Konsepsi Penerapan Asas Horizontal, Bandung : Citra Aditya Bakti.

Kusumaatmadja, Mochtar, 2002, Konsep-konsep Hukum Dalam Pembangunan ( Kumpulan Karya Tulis), Bandung : Alumni.

Sembel. Roy \& Fardiansyah, Tedy, 2002, Sekutitas Derivatif : Madu atau Racun, Salemba Empat, Jakarta.

Sulistyo, Budi, Hedging Nilai Tukar Untuk mengurangi Risiko Pelebaran Defisit Anggaran, Sekretariat Jenderal- Kemenkeu

Wilmott, Paul, 1998, Derivatives - The Theory and Practices of Financial Engineering, New York : John Wiley \& Sons.

\section{Jurnal}

Abubakar, Lastuti, Buletin Hukum Kebanksentralan, Volume 12, No : 1, Januari-Juni 2015.

\section{Peraturan Perundang - Undangan}

PBI No : 16/21/PBI/2014 Tentang Penerapan Prinsip Kehati-hatian Dalam Pengelolaan Utang Luar Negeri Korporasi Non Bank 